\title{
TRACE ELEMENT CONTENTS OF PLANTS AS A FUNCTION OF READILY SOLUBLE SOIL TRACE ELEMENTS
}

\author{
Mikko SillanpäÄ and Esko Lakanen \\ Agricultural Research Centre, Department of Soil Science \\ Tikkurila, Finland
}

Received January 13, 1969

The use of acid ammonium acetate as an extractant in routine soil testing (VuORINEN and MÄкıтIE 1955) has already become established in Finland. Comparisons of soluble major nutrients of soils with those absorbed by plants have supported the use of this method in evaluating the availability of major nutrients in acid soils (KERÄNEN, BARKOFF and JoKINEN 1963, LAKANEN 1963).

In spite of extracting trace elements by this method in studying various soils (LAKANEN 1962, Sillanpä̈̈ and Lakanen 1966, Lakanen and SillanpäÄ 1969), no larger studies have been made to compare acid ammonium acetate extractable trace elements with plant absorbed trace elements.

Because of the great number of trace elements, extractants of more universal character are superior in practical soil investigations. Such extractants as Morgan's solution (acid sodium acetate, $\mathrm{pH} 4.8$ ), a mixture of acetic acid and ammonium sulphate, $\mathrm{pH} 4.0$ (BARON 1955), 0,5 $\mathcal{N}$ acetic acid and $1 \mathcal{N}$ neutral ammonium acetate (Mrtchell 1964) have also been used for multi-element analyses.

This study was conducted to investigate preliminarily to what extent and for which trace elements, acid ammonium acetate could be considered as a suitable extractant in evaluating the availability of soil trace elements to plants.

\section{Material and methods}

The material consists of 216 soil samples and of timothy samples collected from corresponding sites from various parts of the country. Acid ammonium acetate $(0.5 \mathcal{N}$ $\mathrm{CH}_{3} \mathrm{COOH}, 0.5 \mathrm{~N} \mathrm{CH}_{3} \mathrm{COONH}_{4}, \mathrm{pH} 4.65$ ) was used for extracting soluble trace elements from soils. These were separated and concentrated with the aid of pyrrolidinedithiocar- 


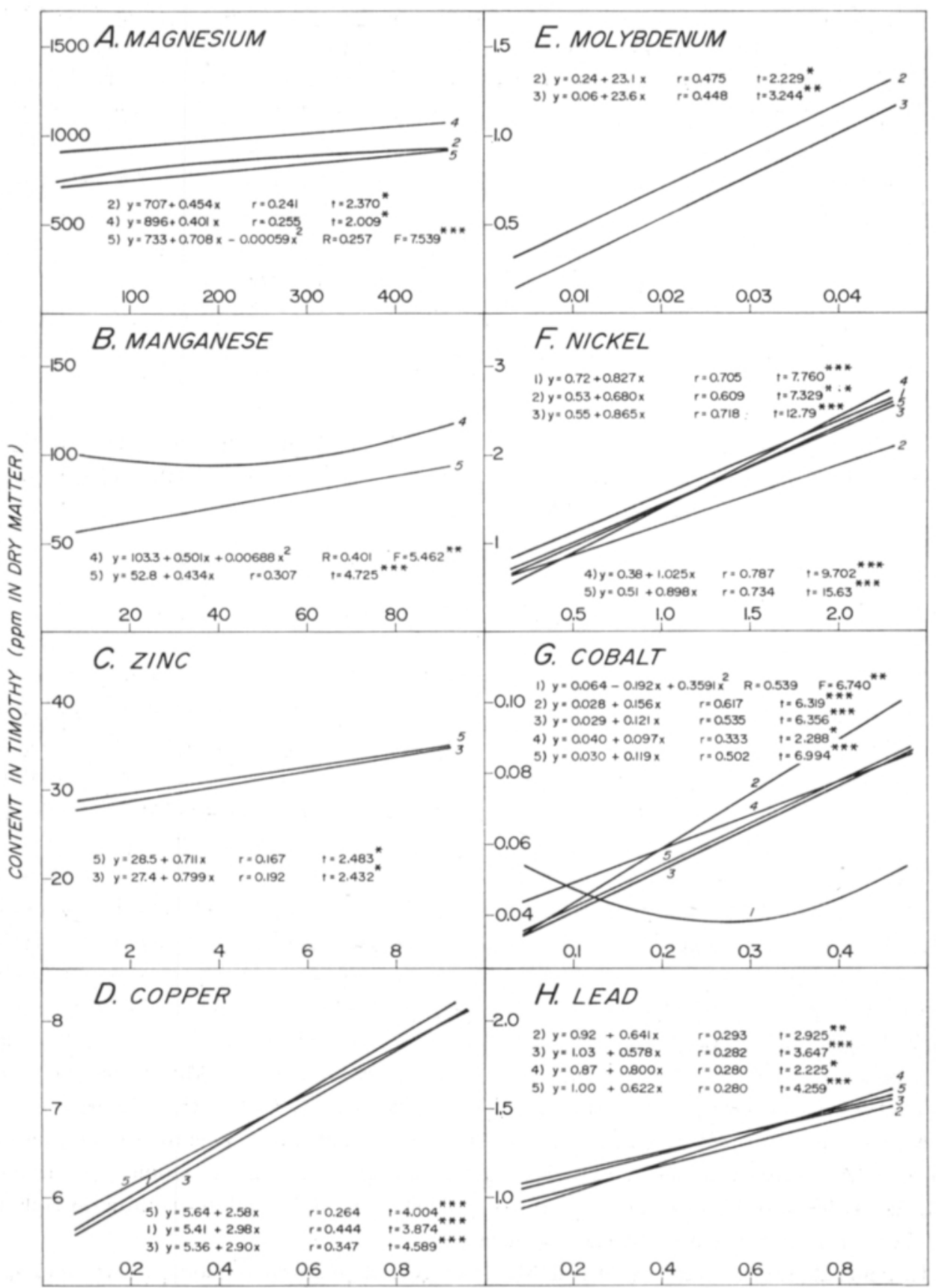

ACID AMMONIUM ACETATE EXTRACTABLE (mg/liter OF SOIL)

Fig. 1. Contents of eight elements in timothy as a function of their contents in various soils as extracted with acid ammonium acetate. (For symbols $1-5$ see p. 62.)

Kuva 1. Kahdeksan alkuaineen pitoisuudet timoteissa vestaavien happameen ammoniumasetaattiin liukoisten maan pitoisuuksien funktiona. (Maalajiryhmät $1-5$ on esitetty sivulla 62.) 
bamic acid. The trace elements of plants were analyzed directly from plant ashes except for cobalt, which was separated and concentrated as above.

The determination of trace elements was made spectrochemically with an ARL $-2-$ meter grating spectrograph. More detailed descriptions of the methods have been given previously (LAKANEN 1961, 1962).

For statistical analyses the material was divided according to soil properties as follows:

1. Clay soils $(>30 \% 2 \mu$ clay $)$

2. Coarse mineral soils

3. Mineral soils (groups $1+2$ )

4. Organogenic soils ( $>15 \%$ humus)

5. Whole material (groups $3+4$ )
63 samples

93 "

156 "

$60 "$

$216 "$

Both linear and curvilinear regressions were calculated. The latter are given in Fig. 1 A-H, however, only in those cases where the fit significantly exceeds that of the linear. The significances are given at $99.9 * * *, 99 * *$ and $95^{*}$ per cent levels.

\section{Results and discussion}

M a g n e s i u m. Magnesium is not among the nutrients usually analyzed in routine soil testing and the correlations between acid ammonium acetate exchangeable and plant $\mathrm{Mg}$ have not been calculated previously. These correlations, given in Fig. $1 \mathrm{~A}$, are significant in the groups of coarse mineral soils and organogenic soils. For the whole material (group 5) the slightly curvilinear regression reaches a very high statistical significance. The relative increase of $\mathrm{Mg}$ content of plants within the variation range of soil $\mathrm{Mg}$ is small.

The behaviour of $\mathrm{Mg}$ in the group of clay soils is obscured and no correlation between the $\mathrm{Mg}$ contents of plants and of soils exists. The high contents of extractable $\mathrm{Mg}$ in clay soils could lead to an assumption that the lack of correlation is due to such an excess of $\mathrm{Mg}$ that the ability of plants to absorb it is exceeded. This, however, can not be correct because the $\mathrm{Mg}$ contents of timothy grown on Finnish clay soils were found to be significantly lower than those of timothy from other soils (LAKANEN 1969). Thus, it is more probable that the reason for this lays in the mechanism by which $\mathrm{Mg}$ is absorbed from clays, in which process e.g. Ca and K play important roles (Marshall 1944).

$\mathrm{M}$ a $\mathrm{n}$ g a n e s e. Correlations between the acid ammonium acetate extractable soil $\mathrm{Mn}$ and $\mathrm{Mn}$ content of plants exist in organogenic soils and in the whole experimental material at 99 and 99.9 per cent significance levels (Fig. 1 B), while in mineral soils the correlations do not reach statistical significance.

In general, the availability of soil $\mathrm{Mn}$ is largely dependent on soil $\mathrm{pH}$. In acid soils, like the soils in this study, the available amounts of Mn generally far exceed the requirements of plants. In some organogenic soils, especially in peats, the Mn level, however, is so low (Sillanpä̈̈ and LaKanen 1966) that it may limit the uptake of Mn by plants. This may explain the correlation in organogenic soils while in mineral soils the abundance of available Mn obscures the correlation. On the other hand, the chelate formations between $\mathrm{Mn}$ and soil organic matter are relatively weak and this may favour weak 
extractants like acid ammonium acetate for determining plant available $\mathrm{Mn}$. The relative increase of $\mathrm{Mn}$ content of plants within the variation range of soil $\mathrm{Mn}$ is somewhat more than that of $\mathrm{Mg}$.

The correlations between soil and plant Mn are apparently weakened by air drying of soil samples, since it is found that the extraction of fresh samples gives a more reliable picture of plant available Mn. To avoid the change of redoxpotential due to drying, the use of reducing agents, e.g. hydroquinone or sodium sulphite, has been recommended (Schachtschabel 1957).

$\mathrm{Z}$ i n c. In extracting soil $\mathrm{Zn}$, acid salt solutions have been used before. HibBard (1943) used potassium chloride buffered to $\mathrm{pH} 3$ with acetic acid. Wear and Evans (1968) compared three extractants, $0.05 \mathcal{N ~ H C l}+0.025 \mathcal{N ~ H}_{2} \mathrm{SO}_{4}, 0.1 \mathcal{N ~ H C l}$ and $0.05 \mathrm{M}$ EDTA for determining the level of plant available $\mathrm{Zn}$ and found the highest correlation with the mixture of $\mathrm{HCl}$ and $\mathrm{H}_{2} \mathrm{SO}_{4}$.

The results of $\mathrm{Zn}$ analyses with acid ammonium acetate are given in Fig. 1 C. Significant correlations at the 95 per cent level exist for mineral soils and for the whole material (groups 3 and 5). It should be noted, however, that especially when analyzing $\mathrm{Zn}$, the correlations obtained characterize the whole analysis process rather than the extraction alone. This is because the variation in the spectrographic analysis of $\mathrm{Zn}$ is wider than for other trace elements under study. This naturally weakens also the correlations given in Fig. 3. The increase of the $\mathrm{Zn}$ content of plants within the variation range of soil $\mathrm{Zn}$ is relatively small.

C o p p e r. The methods used for analyzing soluble soil copper vary greatly in extracting power. The weakest of them are various electrolyte solutions, chelating agents are somewhat stronger and the most effective extractants are strong mineral acids. One of the basic reasons for the heterogeneity of methods is the tendency of copper to form rather stable chelates and complexes with soil organic matter. For example, ØIEN and SEmB (1967) determined soil $\mathrm{Cu}$ with three methods: $0.02 \mathrm{M}$ EDTA solution, $0.043 \mathcal{N}$ nitric acid and with concentrated nitric and perchloric acid digestion. The first two methods were found to give somewhat better estimates of the Cu status in the soil. The ability of acid ammonium acetate to extract copper is relatively weak because it is not a chelating agent nor a strong acid.

Highly significant correlations exist in groups 1, 3 and 5 (Fig. 1 D). The regressions for the three groups are closely similar. The small $\mathrm{Cu}$ fraction extracted apparently represents well the available $\mathrm{Cu}$ fraction in these soils. The increase of plant $\mathrm{Cu}$ as a function of extractable soil $\mathrm{Cu}$ within the variation range of soil $\mathrm{Cu}$ is more than for $\mathrm{Mg}, \mathrm{Mn}$ or $\mathrm{Zn}$.

In the group of organogenic soils the lack of correlation is apparently due to relatively strong copper-organic matter bonds. A closer examination of the material showed also consistently low $\mathrm{Cu}$ contents in both plants and soils in the group of coarse mineral soils. I.e. variation ranges for both were narrow which apparently is one reason for the lack of correlation in these soils. Cu deficiency in Finland has been found in peats and coarse mineral soils.

Moly b d e n u m. The availability of Mo to plants increases generally with increasing soil $\mathrm{pH}$. Also the ability of electrolyte solutions to extract soil Mo increases with increasing solution $\mathrm{pH}$. The reason for both phenomena is the anionic character of molybdate. Consequently, acid ammonium acetate is a weak extractant for soil Mo. Even neutral 
ammonium acetate is more effective (LAKANEN 1962). GRIGG (1953, 1960) has obtained good results with acid ammonium oxalate, $\mathrm{pH} 3.3$, but doubts its reliability for diagnosing Mo deficiencies since it extracts some Fe-bound molybdate which is not available to plants.

In extracting soils with acid ammonium acetate only a very small fraction of Mo is obtained (Fig. 1 E). Significant correlations exist in groups 2 and 3 at 95 and 99 per cent levels respectively.

The relative increase of plant Mo as a function of extractable soil Mo within the variation range of soil Mo, is more than that of any other element under study.

Acid ammonium acetate extractable amounts of Mo from many Finnish soils are so low that in spite of separation and concentration, the amounts to be analyzed spectrochemically are often below the quantitative detection limit.

$\mathrm{N}$ i c k e l. Nickel has not been proved to be essential for plants or for animals. For complementary reasons and because of its close relationship with cobalt (MÄкITIE 1962), the results of $\mathrm{Ni}$ analyses are included in this study. The behaviour of $\mathrm{Ni}$ reflects that of Co and the analysis of $\mathrm{Ni}$ is more reliable because of its higher contents, both in plants and in soils.

The results given in Fig. $1 \mathrm{~F}$ show the best correlations of this study. The significance level of 99.9 per cent was obtained for all soil groups. This indicates both the suitability of acid ammonium acetate for plant available soil Ni extraction and the reliability of spectrographic $\mathrm{Ni}$ analyses. The reproducibility of $\mathrm{Ni}$ determination is clearly better than e.g. that of $\mathrm{Zn}$ discussed above.

In coarse mineral soils the extractable $\mathrm{Ni}$ content is lower than in other soils and also the regression line slopes more gently.

$\mathrm{C} \mathrm{o} \mathrm{b} \mathrm{a} \mathrm{l} \mathrm{t.} \mathrm{The} \mathrm{contents} \mathrm{of} \mathrm{Co} \mathrm{in} \mathrm{plant} \mathrm{ashes} \mathrm{were} \mathrm{too} \mathrm{low} \mathrm{for} \mathrm{direct} \mathrm{spectrochemical}$ determination. Because of this, the ashes from a part of the sample material were dissolved and Co was concentrated before spectrochemical analysis. Co analyses were made from 147 plant samples grown on the following soils: 36 clays, 67 coarse mineral soils and 44 organogenic soils.

In spite of the smaller quantity of sample material, statistically significant correlations were obtained in all 5 soil groups as in the case of $\mathrm{Ni}$. Linear regressions dominate, even though in the group of clay soils a parabola proved to be more significant than the corresponding linear regression. The latter sloped very gently and thus differed clearly from the others.

In spite of the fact that only a very small fraction of the extractable soil Co is transferred to plant tissues, acid ammonium acetate seems to be a suitable diagnosing reagent for estimating the availability of cobalt to plants.

L e a d. As another non-essential trace element lead is included in this study. Lead, as all trace elements, is toxic both to plants and to animals if it exists in too high concentrations. In the present material, however, no lead toxicity is to be expected.

The results of $\mathrm{Pb}$ analyses given in Fig. $1 \mathrm{H}$ show a good agreement between the soil and plant analyses. Significant correlations exist in four out of five soil groups.

\section{$S u m m$ ary}

The use of acid ammonium acetate $(\mathrm{pH} 4.65)$ as an extractant for plant available trace 
elements (Mg included) was studied on a total of 216 soil samples and of timothy samples from corresponding sites.

Significant correlations between the results of soil and plant analyses were obtained for the eight elements studied in following soil groups:
(1) Clay soils
(2) Coarse mineral soils
(3) Mineral soils (Groups $1+2$ )
(4) Organogenic soils
(5) Whole material

\author{
$\mathrm{Ni}, \mathrm{Co}, \mathrm{Cu}$ \\ $\mathrm{Ni}, \mathrm{Co}, \mathrm{Pb}, \mathrm{Mg}, \mathrm{Mo}$ \\ $\mathrm{Ni}, \mathrm{Co}, \mathrm{Pb}, \mathrm{Cu}, \mathrm{Mo}, \mathrm{Zn}$ \\ $\mathrm{Ni}, \mathrm{Co}, \mathrm{Pb}, \mathrm{Mg}, \mathrm{Mn}$ \\ $\mathrm{Ni}, \mathrm{Co}, \mathrm{Pb}, \mathrm{Cu}, \mathrm{Mg}, \mathrm{Mn}, \mathrm{Mo}, \mathrm{Zn}$.
}

\section{REFERENCES}

BARon, H. 1955. Gemeinsame Extraction und chemische Bestimmung des leichtlöslichen Anteils der Mikronährstoffe Bor, Eisen, Kobalt, Kupfer, Mangan, Molybden und Zink in Boden. Landw. Forsch. 7: 82-89.

GrigG, J. L. 1953. Determination of the available molybdenum in soils N. Z. J. Sci. Technol. A 34: 405414.

- - 1960. The distribution of molybdenum in the soils of New Zealand. I. Soils of the North Island. N. Z. J. Agric. Res. 3: 69-86.

Hibbard, P. L. 1943. Comparative amounts of zinc extracted from soils by a chemical solvent and by plants. Soil Sci. 56: 433-442.

KerÄnen, T. \& BARKoff, E. \& Jokinen, R. 1963. Vergleich einiger für die Beurteilung des Nährstoffzustandes der Böden gebrauchlichen chemischen Analysenmethode. Ann. Agric. Fenn. 2: 19-32.

Lakanen, E. 1961. A method for determination of inorganic components of plants. Agrogeol. Publ. 77: 126.

$-\gg-1962$. On the analysis of soluble trace elements. Ann. Agric. Fenn. 1: 109-117.

$\longrightarrow$ - 1963. A comparison of three extractants used in routine soil analysis. Ibid. 2: 163-168.

$\longrightarrow-1969$. Mineral composition of Finnish timothy. Ibid. (in press).

——— \& SillanPäÄ, M. 1967. Strontium in Finnish soils. Ibid. 6: 197-207.

$\longrightarrow$ - \& $\rightarrow$ 1969. Soil factors affecting the calcium strontium ratio of plants. Ibid. (in press.).

Marshall, C. E. 1944. The exchangeable bases of two Missouri soils in relation to composition of four pasture species. Missouri Agric. Exp. Sta. Res. Bull. 385.

Mrtchell, R. L. 1964. The spectrochemical analysis of soils, plants and related materials. Commonw. Bur. Soil Sci. Techn. Comm. 44 A. 225 p.

MĂкıтıE, O. 1962. On the cobalt/nickel ratio in arable soils. J. Sci. Agric. Soc. Finl. 34: 91—95.

SснаснтsснавеL, P. 1957. Die Bestimmung des Manganversorgungsgrades von Böden und seine Beziehung zum Auftreten der Dörrfleckenkrankheit bei Hafer. Z. Pfl.ernähr. Düng. Bodenkunde 78: 147-167.

SillanpäÄ, M. \& Lakanen, E. 1966. Readily soluble trace elements in Finnish soils. Ann. Agric. Fenn. 5: 298-304.

Vuorinen, J. \& MÄкıтıE, O. 1955. The method of soil testing in use in Finland. Agrogeol. Publ. 63: 1-44.

WEAR, J. I. \& EVANS, C. E. 1968. Relationship of zinc uptake by corn and sorghum to soil zinc measured by three extractants. Soil Sci. Soc. Amer. Proc. 32: 543-546.

ØIEN, A. \& SEMB, G. 1967. Undersekelse av analysemetoder for kopper i jord ved hjelp av karforsek og planteanalyser. Forsk. og Fors. i Landbr. 18: 98-97. 


\title{
SELOSTUS
}

\section{HAPAN AMMONIUMASETAATTI KASVEILLE KÄYTTÖKELPOISTEN HIVENAINEIDEN UUTTONESTEENÄ}

\author{
Mikko Sillanpää ja Esko Lakanen
}

Maatalouden tutkimuskeskus, Maantutkimuslaitos, Tikkurila

Happamen ammoniumasetaatin $\left(0.5 \mathrm{~N} \mathrm{CH}_{3} \mathrm{COOH}, 0.5 \mathrm{~N} \mathrm{CH}_{3} \mathrm{COONH}_{4}\right.$, pH 4.65) käyttö viljavuustutkimuksessa on jo vakiintunut Suomessa ja sen soveltuvuutta pääravinteiden uuttamiseen tukevat monet tutkimukset. Sitä on käytetty myös hivenaineiden uuttamiseen maasta, joskaan tämän helppoliukoisen hivenainefraktion kasveille käyttökelpoisuutta ei ole riittävästi tutkittu.

Maan hivenravinnetutkimuksia vaikeuttaa uuttomenetelmien kirjavuus. Usean hivenaineen määrittäminen maasta käytännön mittakaavassa viljavuustutkimusta täydentäen edellyttää mahdollisimman monen hivenaineen samanaikaiseen uuttamiseen soveltuvaa uuttomenetelmää. Tässä tutkimuksessä selvitetään alustavasti happamen ammoniumasetaatin soveltuvuutta tällaiseksi yleisuuttonesteeksi kasveille käyttökelpoisten hivenaineiden määriä arvioitaessa.

\section{Aineisto ja menetelmät}

Aineisto käsittää 216 eri puolilta maata otettua maanäytettä sekä nãytteet vastaavilla paikoilla kasvaneesta timoteiheinästä. Näytteet edustavat oloissamme lähinnä normaalia kasvustoa ja satotasoa. Maanäytteet uutettiin tunnin ajan happamella ammoniumasetaatilla 1:10 tilavuussuhteessa. Uutteiden hivenaineet erotettiin ja rikastettiin pyrrolidinditiokarbamihapolla sekä määritettiin ARL:n 2-m hilaspektrografilla. Kasvien hivenaineiden pitoisuudet määritettiin spektrokemiallisesti suoraan kasvituhkista lukuunottamatta kobolttia, joka ensin rikastettiin määritystä varten edellä mainitulla tavalla (LAKANEN 1961, 1962).

Tulosten tilastomatemaattista käsittelyä varten aineisto ryhmiteltiin maalajien perusteella seuraavasti:

\begin{tabular}{|c|c|c|}
\hline 1. Savimaat & & 63 \\
\hline 2. Karkeat kivennäismaat & & 93 \\
\hline 3. Kivennäismaat & (ryhmät $1+2)$ & 156 \\
\hline 4. Eloperäiset maat & & 60 \\
\hline 5. Koko aineisto & (ryhmät $3+4)$ & 216 \\
\hline
\end{tabular}

Maa- ja kasvianalyysien tulosten väliset 1 . ja 2. asteen regressiot laskettiin kullekin hivenaineelle kaikissa maalajiryhmissä. Kuvassa 1 on esitetty vain merkitsevät regressiot ja 1. asteen regressio on korvattu 2. asteen regressiolla silloin, kun sen korrelaatio merkitsevästi ylittää edellisen. Aineiston laajuudesta johtuen satotuloksia ei valitettavasti ollut käytettävissä, mikä saattaa vaikuttaa saatujen korrelaatioiden merkitsevyyteen.

\section{Tulosten tarkastelu}

M a g n e si u m i n pitoisuudet maassa ja kasveissa ylittävät moninkertaisesti tavanomaisen mhivenainetason». Kun happamen ammoniumasetaatin vaihtaman maan $\mathrm{Mg}$ :n ja kasvien ottaman $\mathrm{Mg}$ :n välisiä suhteita ei ole meillä aikaisemmin selvitetty, on se liitetty osana tähän tutkimukseen.

Kuvassa $1 \mathrm{~A}$ on esitetty timotein $\mathrm{Mg}$-pitoisuus maan vaihtuvan $\mathrm{Mg}: \mathrm{n}$ funktiona. Merkitsevät regressiot on saatu maalajiryhmissä 2 (karkeat kivennäismaat), 4 (eloperäiset maat) ja 5 (koko aineisto). Viimeksimainittu regressio on lievästi kaariviivainen ja erittäin merkitsevä $(\mathrm{F}=7.539 * * *)$. Happamen ammoniumasetaatin vaihtaman maan $\mathrm{Mg}: \mathrm{n}$ määrän kasvaessa nousee kasvin $\mathrm{Mg}$-pitoisuus kuitenkin suhteellisen vähän.

M a n g a a n illa on merkitsevä korrelaatio eloperäisten maiden ryhmässä ja koko aineistossa (kuva 1 B), mutta kivennäismaiden ryhmistä se puuttuu. Mangaanin käyttökelpoisuus kasveille riippuu 
olennaisesti maan pH:sta ja redoxpotentiaalista. Happamissa maissa on Mn kasveille käyttökelpoisessa muodossa ja sen määrä ylittää yleensä runsaasti kasvien tarpeen. Eloperäisissã maissa, erityisesti turvemaissa, mangaania voi olla niin vähän, että se rajoittaa kasvien Mn:n ottoa. Tämä selittänee korrelaation eloperäisten maiden ryhmässä, kun taas kivennäismaiden käyttökelpoisen Mn:n ylimäärä voi johtaa selvän korrelaation puuttumiseen. Toisaalta Mn:n ja orgaanisen aineksen välisen kelaatin muodostuminen on suhteellisen heikkoa, mikä osaltaan suosii heikon uuttonesteen kuten happamen ammoniumasetaatin käyttöä määritettäessä kasveille käyttökelpoista mangaania erityisesti eloperäisistä maista. Maanäytteiden kuivattamisen ennen analysointia on todettu vaikeuttavan kasveille käyttökelpoisen mangaanin määritystä maasta.

S i n k k i ä spektrograafisesti analysoitaessa on huomattava, että analyysitarkkuus on selvästi heikompi kuin muilla hivenaineilla ja siitä johtuva hajonta vastaavasti suurempi. Tämä luonnollisesti heikentää maan ja kasvin Zn-pitoisuuksien välisiä korrelaatioita, jotka näin ollen eivät kuvaakaan pelkästään uuttonesteen osuutta. Tilastollisesti merkitsevät korrelaatiot ovat yhdistetyssä kivennäismaiden ryhmässä ja koko aineistossa (kuva $1 \mathrm{C}$ ).

K u p a r i n taipumus pidättyä lujasti maan orgaaniseen ainekseen on johtanut erilaisten ja hyvin voimakkaidenkin (vahvat hapot) uuttonesteiden käyttöön, joihin verrattuna happamen ammoniumasetaatin kuparin uuttokyky on varsin alhainen.

Kuvassa 1 D on esitetty maalajiryhmissä 1, 3 ja 5 saadut erittäin merkitsevät korrelaatiot. Kun niitä kuvaavat regressiosuorat lisäksi ovat lähes samansuuntaisia, on ilmeistä, että uutettu kuparifraktio ilmentää hyvin kasveille käyttökelpoista kuparia näissä maalajeissa. Eloperäisissä maissa kuparin taipumus sitoutua orgaaniseen ainekseen on ilmeisesti syynä korrelaation puuttumiseen. Karkeiden kivennäismaiden Cupitoisuus on kauttaaltaan alhainen samoin kuin niillä kasvaneiden kasvienkin. Kuparin puutetta on Suomessa todettu erityisesti turvemailla ja karkeillakivennäismailla.

M ol y b de e n i n anioniluonteesta johtuen sekä kasvien molybdeenin otto että uuttuva molybdeeni kasvavat $\mathrm{pH}: \mathrm{n}$ kasvaessa. Niinpä esim. ammoniumasetaatti on neuraalina voimakkampi Mo:n uuttaja kuin happamena (LAKANEN 1962). Vain maalajiryhmissä 2 ja 3 on molybdeenille saatu merkitsevät korrelaatiot (kuva 1 E).

Happamen ammoniumasetaatin useista suomalaisista maista uuttamat Mo-määrät ovat niin vähäisiä, että huolimatta erottamisesta ja rikastamisesta ne jäävät alle spektrokemiallisen määritysherkkyyden alarajan.

Nikkeliä ei ole osoitettu kasveille eikä eläimille välttämättömäksi ravinteeksi. Johtuen sen ja koboltin samankaltaisesta käyttäytymisestä maassa sekä sen jälkimmäistä helpommasta analysoitavuudesta on nikkeli kuitenkin sisällytetty tähän tutkimukseen. Nikkelille saatiin kaikissa maalajiryhmissä korrelaatiot 99.9 prosentin luotettavuudella (kuva 1 F). Maalajiryhmien väliset erot ovat suhteellisen vähäiset, joskin karkeiden kivennäismaiden uuttuvan nikkelin pitoisuus on jonkin verran alhaisempi kuin muiden ja regressio muita loivempi. Korrelaatioiden suureen merkitsevyyteen vaikuttaa epäilemättä nikkelianalyysin muita parempi toistettavuus.

K o b o l t i n pitoisuus timotein tuhkassa oli liian alhainen suoraan spektrokemialliseen määritykseen, joten tuhka oli liuotettava ja koboltti rikastettava siitä. Kobolttianalyysejä tehtiin 147:stä timoteinäytteestä, joista 36 edusti savimaiden, 67 karkeiden kivennäismaiden ja 44 eloperäisten maiden kasvustoja. Huolimatta pienemmästä aineistosta saatiin kaikissa maalajiryhmissä merkitsevät korrelaatiot (kuva 1 G). Savimaissa osoittautui parabeli suoraa merkitsevämmäksi kuvaajaksi. Myös savimaille laskettu suoraviivainen regressio poikkesi muista ollen niitä selvästi loivemmin nouseva.

L y i j y ä, kuten nikkeliäkään, ei ole todettu kasveille eikä eläimille välttämättömäksi. Lyijyn merkitys maataloudessa johtuukin sen toksisesta vaikutuksesta, mikäli sitä esiintyy liian suurina pitoisuuksina. Käsiteltävänä olevassa aineistossa ei kuitenkaan ole yhtään edes epäilyttävän korkeata lyijypitoisuutta.

Kuvassa $1 \mathrm{H}$ esitetyt tulokset osoittavat maasta ja kasveista analysoidun lyijyn pitoisuuksien välillä vallitsevan hyvän korrelaation, joka neljässä maalajiryhmässä viidestä on tilastollisesti merkitsevä. 